\title{
THE TRADITIONAL LEADERS' CONSTITUTIONAL CHALLENGES IN SOUTH AFRICA
}

\section{Saul Tourinho Leal ${ }^{1}$}

\begin{abstract}
The intention of this paper is to list the aspects of the South African constitutionalism, so as to position the traditional leaderships opposite the major challenges that South Africa have to cope with in the course of this century. This paper is immersed in constitutional law, but it does not disregard the natural sociologic aspects that the discussion brings into light.
\end{abstract}

Keywords: traditional leaders, contitutional challenges, south africa

\section{PRESENTATION}

The Constitution of South Africa offers a chapter on the traditional leaders, figures that during the apartheid were upheld by common law. Having decision-making power, they affect millions of people, most notably in the rural areas.

Recent xenophobic hostilities, which took the lives of many people, were associated with a speech by one of the most important traditional leader of the country, Goodwill Zwelithini, King of the Zulu Nation, who in a traditional ceremony ordered the foreigners to pick up their belongings and leave. This statement was rectified subsequently by the King. Even so, it gave rise to major controversy.

The country has a constitutional jurisdiction that is praised all around the world, embodied by the Constitutional Court, coupled with important values of diversity, human dignity and fundamental rights. However, it is confronted with the existence of an atypical institution that is endowed with powers, including criminal ones, having to coordinate this both with the constitutionalism and with the accelerated urbanization process.

The phenomenon of symbolic constitutionality and the constitutional transformation create new biases in this scenario, which tend to be stretched as the country becomes more urban, cosmopolitan and full of social demands.

\footnotetext{
${ }^{1} \mathrm{PhD}$ in Constitutional Law from the Catholic University of São Paulo. He was a visiting researcher at the University of Georgetown, in the USA. Contact: stourinho@pn.com.br 
The intention of this paper is to list the aspects of the South African constitutionalism, so as to position the traditional leaderships opposite the major challenges that South Africa have to cope with in the course of this century. This paper is immersed in constitutional law, but it does not disregard the natural sociologic aspects that the discussion brings into light.

\section{CROSSING THE RAINBOW}

Desmond Tutu, a South African Anglican archbishop, a Nobel Prize Winner, immortalized the term "Rainbow Nation", in reference to the diversity of his country and the need to circumvent the differences in order to materialize the project of National unity. In harmony with Tutu's profession of faith, the wonderful preamble of the South African Constitution summons everyone to be united in their diversities.

This ideal succumbed in the first half of 2015 when the country faced xenophobic hostility, most notably in the townships of Johannesburg and Durban. Aggressions, violence, pillage of foreigners' businesses and murders. Episodes closely related to one of the most historical social institutions of South Africa, the traditional leaderships, as it will be discussed below.

Immigrants broaden the diversity of the society. If the South African Constitution praises the diversity, and the arrival of foreigners embodies this value, the mere resistance to them weakens a fundamental constitutional commitment.

Furthermore, the resistance to immigrants does not sustain itself. Paul Collier recalls that, in certain aspects, migration is positive. For him, "greater diversity brings greater variety and so brings stimulus and choice"2.

At the peak of the violence, on a Sunday morning, in Cape Town, I saw the stupefied faces of the people in a cafeteria, when looking at images made by photographer James Oatway and by journalist Beauregard Tromp, shown on the cover of the Sunday Times newspaper.

They showed the stabbing with a knife of Emmanuel Sithole, a Mozambican street vendor who lived in Alexandra, a township. The aggressors were South Africans and were acting in the light of day. Unarmed, he was unable to react. Upon falling to the ground he begged the four criminals for mercy. Enraged, the criminals stabbed daggers into his chest. All of which was witnessed by the crowd.

This case shows another facet, which is the trend towards increment of cruelty when one has spectators. Practically all of the loot of foreigners' businesses during the xenophobic wave of 2015 were observed by citizens and by the lenses of the press. Why is this?

${ }^{2}$ COLLIER, Paul. 2013. Exodus. Immigration and Multiculturalism in the 21st Century. Allen Lane, London, p. 61. vol.08, no. 03, Rio de Janeiro, 2015. pp. 1534-1554 1535 


\section{ETHNICAL DISPUTES}

According to Steven Pinker, from Harvard's Psychology Department, experiments have shown that people punish others more severely when there is an audience watching. He also affirms that men are two times more prone to begin a discussion that turns into a fight "when spectators are around"3. From this perspective, the hyper-inhabited South African townships are extraordinary stages for xenophobic upsurges.

Such events show that, even the population that resides in townships around the cities, carrying out their normal activities in an urban environment, keeps loyalty to their rural ancestors. The reflexes of the traditional leaders' social strength are not restricted to distant rural areas. Through this perspective, in the short-term, South Africa's urbanization will not minimize such traditional power.

For Paul Collier, Professor of Economics and Public Policy in the Blavatnik School of Government at the University of Oxford, each individual exodus is a triumph of the human spirit ${ }^{4}$. In Alexandra, the Mozambican vendor was rescued by journalists. He was able to get to the hospital, but it was too late. He became one more fatal victim.

In 2008, more than 100,000 foreigners ended up in distant fields. In their majority, they were black and dispossessed migrants from African countries, most notably Nigeria, Malawi, Mozambique and Zimbabwe. In that same period, another Mozambican stained with his own blood the colors of the rainbow. Ernesto Nhamuave, 35 years old, likewise a vendor, was burned alive in Alexandra. The images were shown all around the world. He left a widow and four children. Nobody has ever been convicted for the savagery.

The condescendence with a crime practiced by an equal party against someone of the other "tribe" is not an unknown fact. Steven Pinker remembers that the last notorious case of lynching in the United Stated arose in 1955, "when fourteen-year-old Emmett Till, was kidnapped, beaten, mutilated, and killed in Mississippi after allegedly whistling at a White woman. His murderers were acquitted by an all-white jury in a perfunctory trial"s affirms.

In South Africa, the victims of the attacks are usually small businesspersons who come from other African countries. They serve as middlepersons between the consumers of the townships and the consumer goods, most notably the staple ones. In the course of time, they become successful. Thus, the envy arises, intensified by the high level of unemployment, inequality and lack of opportunities. Prosperity becomes a scarce asset for which one is ready to kill or die.

\footnotetext{
${ }^{3}$ PINKER, Steven. 2011. The better angels of Our Nature. A History of Violence and Humanity. London, Penguin Books, pp. 64748.

${ }^{4}$ COLLIER, Paul. 2013. Exodus. Immigration and Multiculturalism in the 21st Century. Allen Lane, London, p. 11.

${ }^{5}$ PINKER, Steven. 2011. The better angels of Our Nature. A History of Violence and Humanity. London, Penguin Books, p. 464. vol.08, n. 03, Rio de Janeiro, 2015. pp. 1534-1554 1536
} 
Steven Pinker explains that the" antipathy toward individual middlemen can easily transfer to antipathy to ethnic groups". For him, "the capital necessary to prosper in middlemen occupations consists mainly of expertise rather than land or factories, so it is easily shared among kin and friends, and it is highly portable". It is common that certain ethnical groups specialize themselves in niches that require middleman, migrating to any community that needs them, where, according to Pinker, "they tend to become prosperous minorities - and targets of envy and resentment" .

The conflict may have a tribal root, which is why it has to be studied associated to the main point of this paper: the traditional leaders and the constitutional treatment that they deserve. The French historiographer Fustel de Coulanges, in his classic La Cité Antique (The Ancient City), says that the tribe, the family and the fratria (a subdivision of the tribe) have become an independent body, with a special cult from which the foreigner was excluded. No new family could be admitted. Two tribes could in no way merge, because their religion opposes to this. But such as many fratrias were united in one tribe, many tribes were able to associate with each other, under the condition that the cult of each one of them should be respected. The city arose from this alliance.

When speaking to The Economist, Jean Pierre Misago, a researcher of the Migration and Society Center in Johannesburg, stated that at least 350 foreigners were assassinated in xenophobic attacks since 2008 in South Africa ${ }^{7}$. These are 350 deaths for something that only tends to grow: migration. The reason for this growth is obvious: "The increase of migration is an inevitable facet of globalization", explains Paul Collier. In view of this fact, the country must make efforts to minimize the tensions. However, some of the traditional leaders have been doing exactly the opposite, as it will be seen below.

\section{LESS RURAL, MORE URBAN: IS THIS A CHALLENGE TO THE TRADITIONAL LEADERS?}

The xenophobic episodes lead to an inconvenient discussion about the constitutional democracy of the South African. Paul Collier reminds one that the ethical support that is most used in the economy is utilitarianism: the most happiness for the greatest number of persons. For him, when applied to matters of immigration, the principle shows that what happens with the native population when receiving migrants does not have any relevant consequences "as long as overall there are global gains from migration".

This connection between migration, urbanization and happiness has been a target of attention by studious persons. Edward Glaeser, from Harvard's Economics Department, for example, presents research in which people report that they are happier in countries that are more urban. In countries where more than half of 
the population is urban, $30 \%$ of the people claim to be very happy and $17 \%$ mention that they are not very happy or are not happy. In nations where more than half of the population is rural, $25 \%$ of the people report that they are very happy and $22 \%$ report unhappiness. Satisfaction with life grows with the participation of the population that lives in the cities, even considering the income and the education of such nations.

The researcher affirms: in a sample of 25 poorer countries, where the levels of per capita GDP are less than $\$ 10$ thousand, the participation of the urban persons stating that they were very happy was greater in 18 countries and less in 7 . The participation of the persons stating that they were not happy was greater in the nonurban regions in 16 countries and less in $9^{10}$. These data fit South Africa perfectly.

This relationship between migration and happiness has also a normative and historic perspective. As an example, the Constitution of the State of Pennsylvania, dated 1776, assured in Article XV the following: "That all men have a natural inherent right to emigrate from one state to another that will receive them, or to establish a new state in vacant countries, or in such countries as they can purchase, whenever they think that thereby they may promote their own happiness" ${ }^{11}$. In South Africa, it should not be different.

Ivan Turok has conducted research concerning South African urbanization and the future of the cities. Next to Jackie Borel-Saladin, Turok points out that housing, basic services and social wellbeing have been propitiated for needy families in an unprecedented scale for contemporaneous international standards. Since 1994, the government has organized and financed the construction of 2.7 million houses, cost-free and with basic services, which now accommodate one in every five South Africans.

Turok and Borel-Saladin point out that electricity, treated water and bathrooms have been delivered to millions of families. They mention the rapid expansion of social benefits that have assured crucial relief for 16 million hungry and deprived children, as well as retired and handicapped persons. Researchers highlight that without a support there would be many more homelessness, diseases, famine and generalized suffering in many urban communities.

These ideas only increment the desire of living in the cities and reduces the sponsoring of rural structures. Ivan Turok and Jackie Borel-Saladin show the growth of the urban population of South Africa since 1994 as being more than 50\%, going from 21 million to 32 million. One of the reasons is the migration, both rural to urban and international. The proportion of the population living in urban areas went from 53\% in 1994 to $63 \%$ presently, and is expected to reach $71 \%$ by 2030 .

From 1996 to 2011, the population of three cities, Johannesburg, Tshwane and Ekurhuleni, increased by approximately two thirds (63\%, or 4 million). The three coastal cities, Cape Town, Thekwini and Nelson

\footnotetext{
${ }^{10}$ GLAESER, Edward. 2011. Os centros urbanos: a maior invenção da humanidade: como as cidades nos tornam mais ricos, inteligentes, saudáveis e felizes (Triumph of the City: How Our Greatest Invention Makes Us Richer, Smarter, Greener, Healthier, and Happier). Translator: Leonardo Abramowicz. Rio de Janeiro: Elsevier: p. 74.

${ }^{11}$ Accesed in May 2015. Available at: http://avalon.law.yale.edu/18th_century/pa08.asp vol.08, nº. 03, Rio de Janeiro, 2015.pp. 1534-1554 1538
} 
Mandela Bay, grew one third (33\% or two million). The rest of the country less than one-fifth (18\%). Ivan Turok and Jackie Borel-Saladin also show that 10\% of the population of the province of Gauteng was born outside of South Africa.

For them, the meaning of international migration for the economic scenario has been insufficiently analyzed and there are few signs that the developers of public policies are thinking any further ahead, in terms of contribution to the enterprising skills and talents of the country ${ }^{12}$.

The figures above are in syntony with Paul Collier. According to Collier, urbanization is "essential for opening the opportunities that enable the mass escape from poverty ${ }^{\prime 13}$. The Professor further affirms that, "contrary to the prejudices of xenophobes" suggests, the "evidence does not suggest that migration to date has had significantly adverse effects on the indigenous populations of host societies" 14 .

The consequence of this is the rising of urban demands. British urban geographer, David Harvey, highlights that the right to the city is much more than a right of individual or group access to the resources that the city embodies: it is the right of changing and reinventing the city pursuant to our most profound desires ${ }^{15}$.

Mass migration to the South African cities is a fact. The ideal is to be able to adapt to them. People migrate to the city because they see in them a chance of accomplishing their aspirations of prosperity and happiness. They are right about this.

What we need to know is if, in the long term, such urbanization will change the constitutional interpretations to be made as regards the traditional leaders. In the next topic we will see the South African constitutional structure of the traditional leaders, their rights, influence, and how the country's constitutionalism deals with them. The first point, however, is to remember a tragic episode that has put those leaderships under the world's spotlight.

\section{WHEN A SPEECH LIGHTS THE WICK}

Assuming the fact that the South African future will be mostly urban and that the life in the cities creates trends that are not so intensely seen in rural zones, such as cosmopolitism, intensification of exchange, flexible customs and engagement of youngsters seeking access to rights, there is no doubt that the future will cause the role of the traditional leaders to be more symbolic.

\footnotetext{
12 TUROK Ivan; BOREL-SALADIN, Jackie. Change and conflict in South African cities. In: Continuity, change and conflict in South African cities. State of the Nation 2014: South Africa 1994-2014: a twenty-year review. Chapter in Monograph, 2014. Authors: M.Nkondo, M.Chitiga-Mabugu, M.Sithole, T.Meyiwa, I.Turok, J.Borel-Saladin, F.Nyamnjoh. See more at: http://www.hsrc.ac.za/en/research-data/view/6609\#sthash.aafEFWWG.dpuf

${ }^{13}$ COLLIER, Paul. 2013. Exodus. Immigration and Multiculturalism in the 21st Century. Allen Lane, London, p. 175.

${ }^{14}$ COLLIER, Paul. 2013. Exodus. Immigration and Multiculturalism in the 21st Century. Allen Lane, London, p. 245.

${ }^{15}$ HARVEY, David. 2014. Cidades rebeldes: do direito à cidade à revolução urbana (Rebel Cities: From the Right to the City to the Urban Revolution). Translation Jefferson Camargo. São Paulo: Martins Fontes, p. 28.
} 
The statement above is justified. Before the upsurge of xenophobia in the Rainbow Nation, traditional leader Goodwill Zwelithini, King of the Zulu Nation, lit the wick. Speaking in his mother language to a crowd in the Pongolo Community, he said:

[W] talk of people [South Africans] who do not want to listen, who do not want to work, who are thieves, child rapists and house breakers... When foreigners look at them, they will say let us exploit the nation of idiots. As I speak you find their unsightly goods hanging all over our shops, they dirty our streets. We cannot even recognize which shop is which, there are foreigners everywhere. (...) We ask foreign nationals to pack their belongings and go back to their countries.

The Zulu King opened the way that culminated with the assassination of another Mozambican worker. As stressed by the distinguished Mozambican writer Mia Couto, in an open letter to President Jacob Zuma, Mozambique was one of the few countries of the continent that received, during the apartheid, South African who were fighting for their rights. Today, Mozambicans are tracked down and assassinated on South African streets.

This has occurred despite the fact that the foreigners have been considered to be vulnerable groups. The Constitutional Court, in this case Khosa and Others v. Minister of Social Development and Others, was of the understanding that foreigners (even those that have permanent residence, having practically all of the rights of the citizens) are vulnerable. According to Minister Yvonne Mokgoro, foreign citizens represent minorities in all of the countries, and have less political capital. In the South African context (prior to 1994), individuals were ostensibly deprived of rights or benefits based on citizenship, when citizenship was governed by race. The Constitutional Court called attention to the ease with which migrants are stigmatized. Hence the need to reinforce their rights.

The decision exposes the frequent need to render compatible the South African constitutional democracy with the traditional leaders, who in their symbolic kingdoms behave following customary law. The Economist has pointed out: "some South Africans wondered why King Goodwill continues to be bankrolled by taxpayers given his pronouncements that clash with the Country's progressive constitution"16.

Inconsequent speeches about migration policies are common in History. Paul Collier reminds that in Great Britain a speech in 1960 went beyond all limits. In it, there was affirmation that the immigration of people coming from Africa and from South Asia would give rise to a surge of inter-ethnical violence.

For Collier, this foolish speech made by a "long-dead minor politician, Enoch Powell, closed down British discussion of migration policy for over 40 years". He states that the "opposition to immigration became so indelibly linked to racism it could not be voiced in mainstream discourse". Collier clarifies that "Powell's manifestly ridiculous prediction of 'rivers of blood' not only closed down discussion, it came to define liberal fears: the great lurking danger was supposedly the potential for interracial violence between immigrants and the indigenous" 17 .

\footnotetext{
${ }^{16}$ South Africa's kings: More trouble than they're worth? The Economist May $2^{\text {nd }}-8$ th 2015, p. 34.

${ }^{17}$ COLLIER, Paul. 2013. Exodus. Immigration and Multiculturalism in the 21st Century. Allen Lane, London, p. 20.
} vol.08, nº. 03, Rio de Janeiro, 2015.pp. 1534-1554 
Both in the speech by Goodwill Zwelithini, the Zulu King, and in the one by politician Enoch Powell in Great Britain, there is ideology. In this regard, Steven Pinker quotes the Russian historiographer Aleksandr Solzhenitsyn when affirming that, "to kill by the millions you need an ideology". For Pinker, "utopian creeds that submerge individuals into moralized categories may take root in powerful regimes and engage their full destructive might"18.

This type of controversy places the traditional leaders under the focused eyes of the society and, principally, of constitutional literature that, fearful of risks for human rights, resumes an ancient discussion about the position that the traditional leaders and their courts should occupy in a constitutional democracy.

Justice Albie Sachs, who had a fundamental role in the development of the Constitution of South Africa, later becoming a member of the Constitutional Court, believes that "traditional leaders who have political ambitions should be free like any other citizens to campaign for high office; they should not, however, be allowed to abuse their position as traditional leaders for personal and political advancement" ${ }^{\prime 1}$.

It is a refined construal of the matter, showing that even before the Constitution one was already thinking about how to prevent the excesses committed under the shelter of customary law, which at times weaken the constitutional values.

\section{THE TRADITIONAL LEADERS}

There seems to be lack of generalized trust in episodes such as xenophobic attacks. Paul Collier mentions two studies that show how lack of trust has been perpetuated in Africa. Historians have amassed approximately 80 violent inter-group conflicts that occurred prior to 1600. Collier quotes Timothy Besley and Marta ReynalQuerol, who codified these conflicts into spatial coordinates and investigated whether they had any correlation with modern conflicts. As a conclusion, the violence of almost four hundred years persists.

The suggestion of the researchers is that the mechanism for transmission of such conflicts is the lack of trust created by violence that has been reverberating for many decades. The non-cooperation can be reinforced by its own moral code of honor: the vengeance (vendetta), where an error is paid for with another error.

Collier highlights that the conflict is a regular aspect of societies that are based on clans. Historically, the clans have been the most common social organizations, and in many poor countries, they continue to be so. The conflict only ends in the community when the code of honor is put aside. An example given by Collier is the end of

\footnotetext{
${ }^{18}$ PINKER, Steven. 2011. The better angels of Our Nature. A History of Violence and Humanity. London, Penguin Books, p. 395. ${ }^{19}$ SACHS, Albie. 1992. Advancing human rights in South Africa. Contemporary South Debates. Cape Town: Oxford University Press, p. 77.
} 
the duels in East Europe during the XIX ${ }^{\text {th }}$ century, when a cultural revolution caused the custom to seem ridiculous ${ }^{20}$.

In South Africa, weeks after the explosive speech, the Local Headquarters of the Traditional Leaders of KwaZulu-Natal announced that it would hold meetings to implement the proposals by King Goodwill Zwelithini as to the foreigners that wished to live in the lands controlled by Ingonyama Trust, a company led by him. The foreigners would have to be introduced by the ambassadors of their countries. If the locals wished to receive them, they should ask for permission of the traditional leader.

Another announced banner was the defeat of the Law of Customary Marriages, which aims at discouraging polygamy. According to the law, for a man to marry another woman he must obtain written authorization of the first spouse. According to the Zulu King, such authorization never existed. Furthermore, the law was developed without his opinion.

These manifestations obviously are not limited to the traditional leaders of the country and cannot be used to create a negative stereotype as to all that they represent in terms of community values and of preservation of the ancestral identity and culture. However, they set the matter on the table.

The administration of justice in the rural areas of South Africa is predominantly conducted by heads of traditional courts ${ }^{21}$. These courts administrate justice founded on customary law and based on an authority that is assured by the laws that preceded the Constitution, of the apartheid era.

The cases in customary law begin in the family councils. If the matter is not resolved, it is forwarded to the leader (headman), who together with his counselors attempts to decide on the case. If this is unsuccessful, the dispute is sent in the form of an appeal to the chief of the traditional court. From there it can proceed to a judge.

It is not possible to affirm that it is something that is usual in contemporaneous constitutional democracies. However, the more complex is the history of a country, the more complex its constitution becomes. In Brazil, the constitutional treatment given to the indigenous communities, as additional protection for the customs and assurance of huge areas of land, customarily generates criticism. Even so, considering the history of the country, the option taken by the Constitution is perfectly admissible.

It does not seem to be any different in South Africa, with the traditional leaders, their courts and the customary law. What changes drastically is that the influence of such structures in South Africa is incredibly greater than that of the indigenous population in Brazil, which consists of some few isolated communities.

\footnotetext{
${ }^{20}$ COLLIER, Paul. 2013. Exodus. Immigration and Multiculturalism in the 21st Century. Allen Lane, London, p. 65.

${ }^{21}$ DE VOS, Pierre (Editor). 2014. FREEDMAN, Warren (Editor). Danie Brand. Christopher Gevers. Karthigasen Govender. Patricia Lenaghan. Douglas Maiula. Nomthandazo Ntlama. Sanele Sibanda. Lee Stone. South African Constitutional Law in Context. London: Oxford University Press Southern Africa, p. 247.
} 
It is precisely for this reason that the matter becomes more delicate. With the power that the traditional leaders have over the rural communities, it becomes disturbing to know how the urban future of South Africa, allied with an increasingly intense concretization of the Constitution, will deal with them.

This is because, as the philanthropist Nicolas Berggruen affirms, structures of governance rooted on realities of the past do not adjust to the era of information and globalization ${ }^{22}$. The rural and customary ones will have to be modernized.

Parochial convictions are being applied on borrowed time. Steven Pinker states that "many of the nationalisms of the $19^{\text {th }}$ and early $20^{\text {th }}$ centuries were guided by utopian images of ethnic groups flourishing in their native homelands, often based on myths of ancestral tribes who settled the territory at the dawn of time". He recalls: "this agrarian utopianism laid behind Hitler's dual obsessions: his loathing of Jewry, which he associated with commerce and cities, and his deranged plan to depopulate Eastern Europe to provide farmland for German city-dwellers to colonize"23.

There are many criticisms of the structure of the traditional leaders and the customary law applied by them. For Sindiso Mnisi Weeks and Aninka Claassens, the norms of customary law fulfill those that are already created and arbitrarily established, which are "tribal" barriers outlined in apartheid. They also suppress and distort the identity of the vernacular local groups, inserting them in the "traditional communities", under the imposed and often controversial limits that coincide with those of the tribes in the apartheid. According to them, as they prioritize the top to bottom power of the traditional leaders, the norms effectively exclude the voices of the common rural citizens from participation in the development of the rules that will be conducting them ${ }^{24}$.

In 2003, the Traditional Leadership and Governance Framework Act (TLGFA) became effected. According to Sindiso Mnisi Weeks and Aninka Claassens, the TLGFA reinforces the existence of apartheid structures, under the shelter of a democratic government. All of this under the argument that it concerned a transitory rule.

The TLGFA provided in the sense that the national and provincial government would delegate to the traditional council or traditional leaders powers to deal with the: administration of land; agriculture; health; social security; administration of justice; protection and security; birth, death and customary marriage records; economic development; environment; tourism; management of disasters; management of natural resources; and divulgement of information relative to the policies and programs of the government.

\footnotetext{
${ }^{22}$ BERGGRUEN, Nicolas. GARDELS, Nathan. 2013. Governança inteligente para o século XXI: uma via intermediária entre Ocidente e Oriente (Intelligent Governance for the 21st Century: A Middle Way between West and East). Translation by Martim Cardoso. Rio de Janeiro: Objetiva, p. 172.

${ }^{23}$ PINKER, Steven. 2011. The better angels of Our Nature. A History of Violence and Humanity. London, Penguin Books, p. 396.

${ }^{24}$ WEEKS, Sindiso Mnisi. CLAASSENS, Aninka. 2012. Tensions Between Vernacular Values that Prioritise Basic Needs and State Versions of Customary Law that Contradict Them. From page 381 to page 402. LAW and Poverty. Perspectives from South Africa and Beyond. Editors Sandra Liebenberg \& Geo Quinot. Juta: Cape Town, p. 391.
} vol.08, nº.03, Rio de Janeiro, 2015.pp. 1534-1554 1543 
For Sindiso Mnisi Weeks and Aninka Claassens, "this is a list with wide scope indeed, and these roles are to be exercised by what is at present an essentially untransformed institution"25.

CLARA, the Communal Land Rights Act, succeeded the TLGFA in 2004. The Constitutional Court defeated that legislation in May 2010. According to the Court, "traditional leaders, through traditional councils, [would] now have wide-ranging powers in relation to the administration of communal land"26.

Another criticism made by Sindiso Mnisi Weeks and Aninka Claassens is that a significant amount of power is conferred on the traditional leaders, denying for the people the right of opting for other jurisdictions. There are severe sanctions, such as forced labor and limited possibilities of appeals. The law only hinders the banishment in a criminal case. In civil legislation, it is possible. There is also no provision permitting that women participate in the structuring of the traditional courts ${ }^{27}$.

The Traditional Courts Bill B15-2008 would therefore effectively close down, according to Sindiso Mnisi Weeks and Aninka Claassens, "the avenues currently available for women to participate in the definition of law and rights in their communities which are, in fact, increasingly employed by women in practice". For the authors, "the fact that in practice the availability of these potential pathways for women's involvement would depend on the decision of the traditional leader alone, is contradictory to both vernacular law and democracy"28.

Chapter 12 of the Constitution, section 211, requires the law to recognize "the institution, status and role of traditional leadership, according to customary law, subject to the Constitution”. The Black Administration Act (BAA) established the traditional courts, combined with section 16, Exhibit 6 of the Constitution ${ }^{29}$.

According to Pierre De Vos, of the University of Cape Town, despite permitting the national law to address the issue, it is strange that the traditional courts be regulated by the BAA, while all of the provisions of this Law were defeated. De Vos reminds that for the Constitutional Court, the BAA is an incomprehensible law of the apartheid which, anachronistically, has survived the transition to a non-racial democracy ${ }^{30}$.

\footnotetext{
${ }^{25}$ WEEKS, Sindiso Mnisi. CLAASSENS, Aninka. 2012. Tensions Between Vernacular Values that Prioritise Basic Needs and State Versions of Customary Law that Contradict Them. From page 381 to page 402. LAW and Poverty. Perspectives from South Africa and Beyond. Editors Sandra Liebenberg \& Geo Quinot. Juta: Cape Town, p. 392.

${ }^{26}$ WEEKS, Sindiso Mnisi. CLAASSENS, Aninka. 2012. Tensions Between Vernacular Values that Prioritise Basic Needs and State Versions of Customary Law that Contradict Them. From page 381 to page 402. LAW and Poverty. Perspectives from South Africa and Beyond. Editors Sandra Liebenberg \& Geo Quinot. Juta: Cape Town, p. 392.

${ }^{27}$ WEEKS, Sindiso Mnisi. CLAASSENS, Aninka. 2012. Tensions Between Vernacular Values that Prioritise Basic Needs and State Versions of Customary Law that Contradict Them. From page 381 to page 402. LAW and Poverty. Perspectives from South Africa and Beyond. Editors Sandra Liebenberg \& Geo Quinot. Juta: Cape Town, p. 393.

${ }^{28}$ WEEKS, Sindiso Mnisi. CLAASSENS, Aninka. 2012. Tensions Between Vernacular Values that Prioritise Basic Needs and State Versions of Customary Law that Contradict Them. From page 381 to page 402. LAW and Poverty. Perspectives from South Africa and Beyond. Editors Sandra Liebenberg \& Geo Quinot. Juta: Cape Town, p. 393.

${ }^{29}$ Section 16 of Schedule 6 of the Constitution: Every court, including courts of traditional leaders, existing when the new Constitution took effect, continues to function and to exercise jurisdiction in terms of legislation applicable to it and anyone holding office as a judicial officer continues to hold office in terms of legislation applicable to that office, subject to any amendment or repeal of that legislation, and consistency with the new Constitution.

${ }^{30}$ DE VOS, Pierre (Editor). 2014. FREEDMAN, Warren (Editor). Danie Brand. Christopher Gevers. Karthigasen Govender. Patricia Lenaghan. Douglas Maiula. Nomthandazo Ntlama. Sanele Sibanda. Lee Stone. South African Constitutional Law in vol.08, nº.03, Rio de Janeiro, 2015.pp. 1534-1554 1544
} 
The BAA assures jurisdiction for the chief, headman and chief s deputy to examine civil issues and certain criminal issues. However, under customary law, the court normally consists of the chief and his councilors, the headman and his advisers. Usually men. In the majority of the cases, the chief does not preside the proceedings. A trustworthy councilor is appointed for this.

Pierre De Vos clarifies that this model changes from community to community. For him, the flexible nature of customary law, together with its ability of developing and adapting to the circumstances, makes it impossible to identify a unified system according to which the traditional courts operate.

Pierre De Vos further states that, as the traditional leaders are involved in the exercise of the legislative and executive functions, it has been questioned whether the traditional courts can be independent, as required by the Constitution. Different Higher Courts have arrived at different conclusions and the Constitutional Court has not yet cast its opinion ${ }^{31}$.

King Goodwill actually is not alone. There are ten traditional kings and one queen. This in addition to the more than 8,000 traditional leaders and the more than 1,500 traditional courts. The Traditional Courts Bill was proposed in 2012, but it was removed thanks to the efforts of the women of the rural communities.

Imagine the difficulty of managing more than 8,000 traditional leaders, all of them taking decisions of undeniable impact on the life of people. According to Alexis de Tocqueville, what created all of the miseries of the feudal society is that the power, not only of administrating but of governing, was shared between thousands of hands and fractioned into thousands of ways; the absence of any governmental centralization thus hindered the nations of Europe from marching with determination in the direction of any objective ${ }^{32}$.

It is not easy to discuss the position of the traditional leaders in the constitutional democracy of South Africa. The traditional leaders are recognized by the Constitution. Chapter 12, sections 211 and 212, states the following:

\section{Recognition.}

1. The institution, status and role of traditional leadership, according to customary law, are recognized, subject to the Constitution.

2. A traditional authority that observes a system of customary law may function subject to any applicable legislation and customs,

Context. London: Oxford University Press Southern Africa, p. 249. See: Western Cape Provincial Government and Others in Re: DVB Behuising (Pty) Limited v North West Provincial Government and Another (CCT22/99) [2000] ZACC 2; 2000 (4) BCLR 347; 2001 (1) AS 500 (2 March 2000) to 1.

${ }^{31}$ DE VOS, Pierre (Editor). 2014. FREEDMAN, Warren (Editor). Danie Brand. Christopher Gevers. Karthigasen Govender. Patricia Lenaghan. Douglas Maiula. Nomthandazo Ntlama. Sanele Sibanda. Lee Stone. South African Constitutional Law in Context. London: Oxford University Press Southern Africa, p. 249.

32 TOCQUEVILLE, Alexis de. 2005. A Democracia na América: leis e costumes de certas leis e certos costumes políticos que foram naturalmente sugeridos aos americanos por seu estado social democrático (The Democracy in America: laws and customs of certain laws and certain political customs that were naturally suggested to the North Americans by their social democratic state). Translation: Eduardo Brandão. São Paulo: Martins Fontes, p. 102. 
which includes amendments to, or repeal of, that legislation or those customs.

3. The courts must apply customary law when that law is applicable, subject to the Constitution and any legislation that specifically deals with customary law.

212. Role of traditional leaders.

1. National legislation may provide for a role for traditional leadership as an institution at a local level on matters affecting local communities.

2. To deal with matters relating to traditional leadership, the role of traditional leaders, customary law and the customs of communities observing a system of customary law-

3. National or provincial legislation may provide for the establishment of houses of traditional leaders; and

4. National legislation may establish a council of traditional leaders.

It is important to know the role of the traditional leader, considering a full reading of the Constitution and a refined comprehension of its fundamental purposes. This document, perhaps more than any other of the end of the $\mathrm{XX}^{\text {th }}$ century, announced in all of its provisions an obvious intention of establishing what Konrad Hesse calls "will for Constitution". For Konrad Hesse ${ }^{33}$, more than a mere picture of the country, the Constitution must direct the society to the future.

\section{SYMBOLIC KINGDOMS}

The perspective outlined by Pierre De Vos concerning the conception on traditional leaderships in the constitutional democracy of South Africa is more than appropriate. For the constitutionalist, what exist are "symbolic kingdoms" 34 .

It is possible to have symbolic kingdoms, symbolic legislations and even symbolic constitutional provisions.

Symbolic legislation is the one in which a political-ideological function prevails in detriment of the legalinstrumental function that has a legal-normative nature.

In the symbolic constitutionality, the Constitutions have provisions with improbable fulfillment, but that would represent some comfort for a portion of the population. The constitutional speech would be vested with an ideological nature, aimed at social pacification, even if full of unrealizable aspirations.

According to Marcelo Neves, the symbolic Constitution is a speech converted into a legal rule, but that even so never left the level of a mere speech addressed to the masses with the purpose of creating in them a relationship of assurance about something that previously one was not sure would materialize.

\footnotetext{
${ }^{33}$ HESSE, Konrad. 1991. A Força Normativa da Constituição (The Normative Strength of the Constitution). Translation: Gilmar Ferreira Mendes. Porto Alegre: Sergio Antonio Fabris.

34 DE VOS, Pierre. Traditional leaders caught in a colonial time warp. Accessed in May of 2015, at: http://constitutionallyspeaking.co.za/traditional-leaders-caught-in-a-colonial-time-warp/. vol.08, nº. 03, Rio de Janeiro, 2015.pp. 1534-1554 1546
} 
When one affirms that the traditional leaderships and their courts are symbolic, one does not intend with such affirmation to create any stereotype that diminishes their historical importance. Actually, to affirm that they are symbolic means that they effectively do not have a normative structure that derives naturally from the legal norm. They are much more connected to a rhetoric postponement deriving from the political process that is interested in avoiding conflicts.

Justice Albie Sachs, praising the importance of the traditional leaders, did not fail to observe a symbolic nature in their positions. For Sachs, "their symbolical position for the community, their religious and ceremonial functions, their relationship with the land, with the spirit, with the ancestors, is deeply bound up with the customs and ethos of the particular community" ${ }^{\prime 35}$.

It is important to delve deeper into the symbolic issue. Marcelo Neves states that the symbolic constitutionality creates the need to promote trust in the State or in the government, serving for them as a formula for rhetoric representation. It shows that the discredit on the part of the population in relation to the State can be a serious consequence of such symbolic option.

Neves addresses the symbolic constitutionality in three categories: 1) the symbolic constitutionality intended for corroboration of certain social values; 2) the Constitution as a formula of expanding commitment; and 3) the constitutionality-alibi. With the symbolic constitutionality, what one obtains is the presentation of constitutional provisions that, without any normative-legal relevance, confirm the beliefs and way of life of certain groups $^{36}$.

Quoting Bryde, Neves affirms that the symbolic Constitutionality, as opposed to the "normative" ones, are above all based on the pretentions (corresponding to the internal or external necessities) of the leading elite by the symbolic representation of their governmental order.

For this reason, no real codification of the process of power derives from them. What exists is a rhetoric postponement of the fulfillment of the constitutional model to a remote future, as if this were possible without radical transformations in the relationships of power and in the social structure ${ }^{37}$.

The theme above presents the scenario of Chapter 12 of the Constitution of South Africa. Hence Pierre De Vos' correctness when speaking of "symbolic kingdoms".

\section{CONSTITUTIONAL TRANSFORMATION}

\footnotetext{
${ }^{35}$ SACHS, Albie. 1992. Advancing human rights in South Africa. Contemporary South Debates. Cape Town: Oxford University Press, p. 78 .

${ }^{36}$ NEVES, Marcelo. 2007. A constitucionalização simbólica (The symbolic constitutionality). São Paulo: WMF Martins Fontes, p. 102.

${ }^{37}$ NEVES, Marcelo. 2007. A constitucionalização simbólica. São Paulo: WMF Martins Fontes, p. 105. vol.08, no. 03, Rio de Janeiro, 2015.pp. 1534-1554 1547
} 
Considering the consolidation of the constitutional democracy of the country, the courageous exercise of constitutional jurisdiction by the Constitutional Court, the universal values rooted in the XXI ${ }^{\text {st }}$ century, and the undeniable urbanization phenomenon, Chapter 12 of the Constitution of South Africa heads towards its transformation.

The constitutional transformation consists of the phenomenon by which a provision of the Constitution can have its sense completely altered on account of factual and legal changes, so that it is no longer possible to attribute to it the same former sense. This being without any change in its wording.

The fact that the Constitution of South Africa was established almost 20 years ago is not an obstacle for transformation of one of its provisions. For Konrad Hesse, one cannot accept that a constitutional transformation can require a lapse of time that is either more or less extended; in any case, it cannot concern an element of definition: the processes that give way to a constitutional transformation have no relation with the nature either more or less remote of the beginning of effectiveness of the Constitution, and can occur upon many years, but also within a short period ${ }^{38}$.

Reality shows the need for a re-reading of the Constitution. Karl Loewenstein teaches us: in the constitutional transformation, there is production of a transformation in the reality of the configuration of the political power of the social structure and of the equilibrium of interests, without the mentioned transformation being incorporated with the constitutional document: the text of the constitution remains intact ${ }^{39}$.

Chapter 12 of the Constitution of South Africa, experiencing an inevitable process of transformation, will proceed to consider the traditional leaderships and their courts as symbolic kingdoms to which future generations owe consideration and respect, but the authority of which does not challenge the Constitution.

The traditional leaders have already become targets of a kind of polishing on the part of the Constitutional Court. In the Shilubane and Others v Mwamitwa case, the Court understood that the traditional community can alter rules to permit that children of the feminine gender can reign, while revoking the former sexist ones. In another opportunity, it affirms that customary law is part of the legal system (Alexkor v Richtersveld Community). Nevertheless being subject to the Constitution.

The Constitutional Court also affirmed that the courts must consider the fact that customary law, such as any law, regulates people's lives. The need for flexibility and the imperative of facilitating its development must be balanced with the value of the legal security, respect for invested rights and protection of the constitutional rights.

Pierre De Vos recalls the case of Princess NormaXhosa Sigcawu, of East Cape, who, having been hindered from assuming the throne of the Kingdom of AmaGcaleka, sought aid from the Constitutional Court,

\footnotetext{
${ }^{38}$ HESSE, Konrad. 2009. Temas Fundamentais do Direito Constitucional (Fundamental Themes of Constitutional Law). Text selected and translated by Carlos dos Santos Almeida, Gilmar Ferreira Mendes and Inocêncio Mártires Coelho. São Paulo: Saraiva, p. 152.

${ }^{39}$ LOEWENSTEIN, Karl. 1976. Teoria de La Constitución (Theory of the Constitution). Barcelona: Ariel, p. 164. vol.08, nº.03, Rio de Janeiro, 2015.pp. 1534-1554 1548
} 
sustaining that her impediment, upheld by a traditional leader based on customary law, violated the Constitution because its grounds were sexist: she was a woman.

The mother of the princess, Queen Nozizwe, had been the principal wife of King Zwelidumile Sigcawu. When he died, the princess was still a baby. Her brother, King Xolilizwe, the son of another woman, inherited the crown. When he died in 2006, Mpendulo, the following son, assumed the throne. According to the princess, the rule of customary law states that the oldest male son is the heir of the throne. According to her, it is a norm that discriminates according to the gender or sex, thus being unconstitutional.

Chief Patekile Holomisa, president of the Congress and Traditional Leaders of South Africa (CONTRALESA), stated that the custom must establish who will become leader, as the legitimacy of the ubukhosi derives from the customs, does not derive from the Constitution and from the Fundamental Rights.

The resistance to the Constitutional State has a number of causes. For Daron Acemoglu and James Robinson, inclusive institutions require that the state can impose the law and the order, defend the rights of property and foment the economic activity, when necessary by means of investment in public services. They comprise the resistance on the part of the local authorities. The reason is the fear, which is almost always justified, that it will displace the axle of the political power, transferring it from those who dominate presently to the hands of new individuals and groups ${ }^{40}$.

For Pierre De Vos, in cases like the one of Princess NormaXhosa Sigcawu, the Court should not expect the traditional community to apply its customary law until it overcomes the unconstitutionality. The correct would be to defeat the rule.

According to De Vos, customary law will only occupy its proper place next to common law when the structures of the traditional leaderships are completely reformed and democratized. This is because, for the Professor, the current system is anti-democratic and often oppressive, and finds no room in a Constitutional democracy ${ }^{41}$.

In another case, residents of the Motlhabe Village, one of the 32 villages that make up the Bakgatla-baKgafela traditional community in Pilanesberg, in the North East province, were hindered by the Higher Court from holding a meeting to discuss the situation of the community, with obvious criticisms of its leader.

Kgotha Kgothe is a traditional assembly in which the members of the traditional community discuss and decide on matters relative to the community, which includes assessing and criticizing the performance of its leaders. The argument was that a Kgotha Kgothe can only be called by the leader, - Kgosi - or a delegating official -

\footnotetext{
${ }^{40}$ ACEMOGLU, Daron. ROBINSON, James A. 2012. Por que as nações fracassam: as origens do poder, da prosperidade e da pobreza (Why Nations Fail: The Origins of Power, Prosperity, and Poverty). Translation by Cristiana Serra. Rio de Janeiro: Elsevier, p. 189.

${ }^{41}$ DE VOS, Pierre. Time for rethink on traditional leaders. Jun 28th, 2010. Accessed in May of 2015 at: http://constitutionallyspeaking.co.za/time-for-rethink-on-traditional-leaders/.
} 
the Kgosana. However, for the members of the community it did not concern calling an official assembly but only holding a meeting between those interested in discussing matters that are common to everyone. The conflict ended up in the Constitutional Court, by means of the Pilane and Another case.

For the majority of the Court, in the core of the series of summons issued against parties interested in the event, there was the intention of the leader - Kgosi - of suppressing the democratic rights that annoy the members of the Traditional Community. The majority connected the liberty of expression to the right of association and meeting, reputed as being the health of the South African democracy. According to the Court, it is a value that is inherent to the permission that diverging voices can be heard and thus there are robust discussions that strengthen the institutions and democracy. The majority decision actually defined the attempt of hindering the meeting as worrisome.

According to Pierre De Vos, this dissidence on how to protect the right of those that wish to express their dissatisfactions with the conducts of the leaders that were imposed upon them anti-democratically suggests two different visions of the rules of the traditional leaderships in South Africa. This further shows the difference, for the different concepts of justice - the constitutional and the traditional - concerning the value of the divergence and the right of those who wish to criticize their leaders ${ }^{42}$.

The transformation of Chapter 12, which must be recognized by the Constitutional Court, requires the traditional leaderships to be seen as being in harmony with the Constitution.

According to section 39 (2) and (3), addressing the construal of the Bill of Rights, (2) "when interpreting any legislation, and when developing the common law or customary law, every court, tribunal or forum must promote the spirit, purpose and objects of the Bill of Rights". It also states: (3) "the Bill of Rights does not deny the existence of any other rights or freedoms that are recognized or conferred by common law, customary law or legislation, to the extent that they are consistent with the Bill".

Thus, both the traditional courts and the decisions emanated from their leaders, such as customary law itself, must respect the Bill of Rights, which includes rights such as the prohibition of slavery, servitude and forced labor (s 13); freedom of religion, belief and opinion (s 15); freedom of expression. (s 16); assembly, demonstration, picketing and petition (s 17); and freedom of association (s 18).

The Constitution did not assure privileges for the typical traditional leaders of the authorities of State, such as, for example, the members of Parliament. This silence is more than eloquent. Cabinet members, Deputy Ministers and members of the National Assembly, "have freedom of speech in the Assembly and in its committees, subject to its rules and orders; and are not liable to civil or criminal proceedings, arrest, imprisonment or damages for anything that they said in, produced before or submitted to the Assembly or any of its committees;

42 DE VOS, Pierre. Democracy vs. traditional leadership: the delicate ballet. Accessed in May of 2015: http://www.dailymaverick.co.za/opinionista/2013-03-06-democracy-vs-traditional-leadership-the-delicateballet/\#.VU39ginvbdk. 


\section{Quaestio Iuris}

or anything revealed as a result of anything that they have said in, produced before or submitted to the Assembly or any of its committees" [s 58 (a)(b)(i)(ii) of the Constitution].

Without enjoying the privileges such as those mentioned above, the traditional leaders answer in their own words. It concerns an eloquent silence that conveys the message as to the new democracy.

Counting with the respect of everyone, and the consideration of their communities, the traditional leaders and their courts may be deemed equivalent to all of the plural institutions that the South African democracy detains, the so-called civil society, such as non-governmental organizations, associations, unions or organized movements. This idea had already been given by Albie Sachs, even before development of the Constitution of South Africa, as we will see ahead.

\section{THE OTHER SIDE OF THE RAINBOW}

"Mr. President, the xenophobia seen today in South Africa is not merely a barbaric and cowardly attack against others. It is also an aggression against South Africa itself. It is an attack against the 'Rainbow Nation', which South Africans proudly proclaimed over a decade or more ago", was commented in an Open Letter to President Jacob Zuma by Mozambican writer Mia Couto.

The Rainbow Nation has inspired the world. It will never fail to inspire. However, it is time to perceive that, having reached its twenty years, it begins its new journey towards adult life, which requires natural transformation.

With unprecedented urbanization, South Africa will have to reinvent itself. Still within the current century, the country will become increasingly young, urban and aware of its rights. Global will triumph over tribal; urban, instead of rural; science in the place of mysticism; respect for rights, instead of for strength; and with a trend towards democracy, rejecting authoritarianism. Thus, what is the role of the traditional leaders?

Chapter 12 of the South African Constitution can be seen as being something that is symbolic that heightened its respect for the past, assuming a political position. This option, which is natural in complex societies, every day faces new challenges. Thus the need to recognize the transformation of the norm.

The chapter will incur a re-reading, positioning the traditional leaders and their courts as relevant organizations, such as the associations or unions. One does not disagree with this. It is simply a natural consequence of the values and purposes that are enjoyed by a Constitution. 
Writing in this regard, Albie Sachs clarified that "conventional constitutional nations tend to base themselves on the existence of three constitutionally relevant entities, namely, the state, political parties and individuals. More recently emphasis has been put on a fourth element, namely organizations of civil society”33.

According to Sachs, "such organizations are obtaining increasing constitutional acknowledgement, not as part of the state, nor as transmission belts for political parties, nor as mere aggregates of individuals. They are regarded as collective bodies contributing towards the richness and texture of social life and enjoying the right to autonomous spheres of action, provided that their activities do not suppress or interfere with the rights of others". As examples, he quotes: "religious bodies, trade unions and sporting and cultural associations"

Thus, concerning the traditional leaderships, their kings and queens, their courts, and the customary law by which they guide their conducts, there must be application of a treatment that is not different from what is conferred on the organizations of the civil society.

They must respect the Constitution, their structures must the subject to accountability, their leaders need to stipulate mechanisms of alternation of power, it is necessary to have legitimacy on such leadership and all of decisions must be cast after they have been subjected to the constitutional pillar of due legal process.

The more the constitutional leaders are adapted to the Constitution, the more their eternity will be assured. The more they can be democratic, the more legitimate will be their decisions. The more respect they have for diversity - assured by the Constitution - the more modern they will be, establishing a vivid customary law, much more concerned in establishing the bases for tomorrow than with continuing chains to a past that in certain aspects is gone.

\section{CONCLUSION}

The Constitution of South Africa was developed under circumstances that the whole world understands, suppressed by the strength of the facts and anxious for the winds of democracy to destroy the barricade of the apartheid.

Chapter 12, which addresses the traditional leaders, has a symbolic nature, assuming an appearance that is more political than legal, more rhetoric than normative. Nevertheless with the respect and consideration of the constitutional jurisdiction.

\footnotetext{
${ }^{43}$ SACHS, Albie. 1992. Advancing human rights in South Africa. Contemporary South Debates. Cape Town: Oxford University Press, p. 81.

${ }^{45}$ SACHS, Albie. 1992. Advancing human rights in South Africa. Contemporary South Debates. Cape Town: Oxford University Press, p. 82 .
} 
In view of its symbolic nature, allied with the intense urbanization of South Africa, it is natural to presume that the traditional leaderships somewhere in the future will have to submit to a construal that recognizes the transformation of the provision. The case relative to the xenophobic attacks served to illustrate the tension that from time to time develops between the traditional leaderships and the constitutional democracy.

Chapter 12 must proceed to rely on a construal that understands the traditional leaderships as being associations of the civil society, consisting of members that freely and spontaneously agreed to be members of such community by following its rules. Rules that respect the Constitution, of course.

\section{ACKNOWLEDGEMENTS}

This paper was conducted at the University of Cape Town, under orientation of Professor of Constitutional Law, Pierre De Vos. In addition to thanking for the availability, kindness and assurance of Professor Pierre, I am grateful for the structure of the UCT made available to me and for the essential role of Professor Elrena van der Spuy, Head of the Public Law Department.

Lastly, for all of the students of the UCT that, guided by their convictions and hearts, have been fighting for an even better South Africa.

\section{DESAFIOS CONSTITUCIONAIS DOS LIDERES TRADICIONAIS NA AFRICA DO SUL}

\section{Resumo}

Este artigo tem como intenção listar os aspectos do constitucionalismo Sul Africano, de modo a posicionar as lideranças tradicionais frente aos principais desafios que a África do Sul têm de enfrentar no decorrer deste século. Este trabalho está imerso em direito constitucional, mas sem desconsiderar os aspectos naturais sociológicos que a discussão traz à tona.

Palavras-chave: líderes tradicionais, os desafios contitutional , áfrica do sul REFERENCES

ACEMOGLU, Daron. ROBINSON, James A. 2012. Por que as nações fracassam: as origens do poder, da prosperidade e da pobreza (Why Nations Fail: The Origins of Power, Prosperity, and Poverty). Translation by Cristiana Serra. Rio de Janeiro: Elsevier.

BERGGRUEN, Nicolas. GARDELS, Nathan. 2012. Governança inteligente para o século XXI: uma via intermediária entre Ocidente e Oriente (Intelligent Governance for the 21st Century: A Middle Way between West and East). Translation by Martim Cardoso. Rio de Janeiro: Objetiva.

COLLIER, Paul. Exodus. 2013. Immigration and Multiculturalism in the 21st Century. Allen Lane, London. 
GLAESER, Edward. 2011. Os centros urbanos: a maior invenção da humanidade: como as cidades nos tornam mais ricos, inteligentes, saudáveis e felizes (Triumph of the City: How Our Greatest Invention Makes Us Richer, Smarter, Greener, Healthier, and Happier). Translator: Leonardo Abramowicz. Rio de Janeiro: Elsevier.

HARVEY, David. 2014. Cidades rebeldes: do direito à cidade à revolução urbana (Rebel Cities: From the Right to the City to the Urban Revolution). Translation by Jefferson Camargo. São Paulo: Martins Fontes.

HESSE, Konrad. 2009. Temas Fundamentais do Direito Constitucional (Fundamental Themes of Constitutional Law). Texts selected and translated by Carlos dos Santos Almeida, Gilmar Ferreira Mendes e Inocêncio Mártires Coelho. São Paulo: Saraiva.

LOEWENSTEIN, Karl. 1976. Teoria de La Constitución. Barcelona: Ariel.

NEVES, Marcelo. 2009. A Constitucionalização Simbólica (The Symbolic Constitutionalism). São Paulo: WMF Martins Fontes.

PINKER, Steven. 2011. The better angels of Our Nature. A History of Violence and Humanity. London, Penguin Books.

TUROK, Ivan. BOREL-SALADIN, Jackie. Change and conflict in South African cities. Chapter of a book.

TOCQUEVILLE, Alexis de. 2005. A Democracia na América: leis e costumes de certas leis e certos costumes políticos que foram naturalmente sugeridos aos americanos por seu estado social democrático ((The Democracy in America: laws and customs of certain laws and certain political customs that were naturally suggested to the North Americans by their social democratic state). Translation by Eduardo Brandão. São Paulo: Martins Fontes.

DE VOS, Pierre (Editor). 2014. FREEDMAN, Warren (Editor). Danie Brand. Christopher Gevers. Karthigasen Govender. Patricia Lenaghan. Douglas Maiula. Nomthandazo Ntlama. Sanele Sibanda. Lee Stone. South African Constitutional Law in Context. London: Oxford University Press Southern Africa.

VOS, Des Pierre. Traditional leaders caught in a colonial time warp. Online at: http://constitutionallyspeaking.co.za/traditional-leaders-caught-in-a-colonial-time-warp/.

Time for rethink on traditional leader. Jun 28th, 2010. Online at: http://constitutionallyspeaking.co.za/time-for-rethink-on-traditional-leaders/.

Democracy vs. traditional leadership: the delicate ballet. Online at: http://www.dailymaverick.co.za/opinionista/2013-03-06-democracy-vs-traditional-leadership-the-delicateballet/\#.VU39ginvbdk.

WEEKS, Sindiso Mnisi. CLAASSENS, Aninka. 2012. Tensions Between Vernacular Values that Prioritise Basic Needs and State Versions of Customary Law that Contradict Them. From page 381 to page 402. LAW and Poverty. Perspectives from South Africa and Beyond. Editors Sandra Liebenberg \& Geo Quinot. Juta: Cape Town.

Trabalho enviado em 04 de junho de 2015.

Aceito em 26 de julho de 2015. 